\title{
PREVALENSI DAN FAKTOR RISIKO ANEMIA PADA REMAJA PUTRI DI SMAN I ABIANSEMAL BADUNG
}

\author{
Febianingsih, Ni Putu Eka ${ }^{1 *}$, Putra, Kadek Agus Dwija ${ }^{1}$, Putra, Gede Yudiana ${ }^{1}$ \\ Indriani, $\mathrm{C}^{2}$, W. Pujana ${ }^{3}$ \\ ${ }^{1}$ Akademi Keperawatan Kesdam IX/Udayana \\ ${ }^{2}$ FETP Fakultas Kedokteran Universitas Gadjah Mada \\ ${ }^{3}$ Dinas Kesehatan Provinsi Bali \\ ${ }^{*}$ Korespondensi: putufebi_ph@yahoo.com
}

\begin{abstract}
Background: High prevalence of anemia exists in the developing country where its causes are multi-factorial. One of the most vulnerable populations are adolescent girl. This study aims to know the prevalence and risk factor of anemia among adolescent girls in Abiansemal High School

Methods: Cross sectional study was conduct with a total of 254 individuals comprising healthy participated. The relevant information was collected with interviews, anthropometric measurements and Hemoglobin assay. Multivariate Poisson Regression analysis was done to analysis the risk factor. Results: The prevalence of anemia was found to be $71.3 \%$ (22.8\% mild anemia, $47.2 \%$ moderate anemia and $1.2 \%$ severe anemia). Mean age of the adolescent girls was $15.5 \pm 0.66$ years old. Multivariate analysis showed that the strongest predictors of anemia associated with adolescent girls is eating frequency $\leq 2$ times a day (aPR:1.55; 95\% CI: 1.32 to 1.81 ), excessive menstrual bleeding (aPR: 1,$35 ; 95 \%$ CI 1.17 to 1.56 ), vegetarian diet (aPR: 1.23 ; $95 \%$ CI 1.08 to 1.41 ) and drinking tea during meals (aPR: $1.17 ; 95 \%$ CI 1.01 to 1.36). However, the level of knowledge, socioeconomic status, and BMI did not contribute significantly in this study. Conclusions: High prevalence of anemia in adolescent girls of Abiansemal High School. Anemia screening should be done regularly and giving iron tablets to adolescent girls.
\end{abstract}

Keywords: Anemia, Adolescents, tea, vegetarian

\begin{abstract}
ABSTRAK
Latar belakang: Prevalensi anemia yang cukup tinggi masih menjadi masalah di negara berkembang yang mana dipengaruhi oleh banyak factor. Salah satu populasi yang paling rentan adalah remaja putri. Studi ini bertujuan untuk mengetahui prevalensi dan factor risiko anemia pada remaja putri di SMAN I Abiansemal, Badung. Metode: Penelitian cross sectional dilakukan dengan melibatkan 254 orang peserta sehat. Informasi yang relevan dikumpulkan dengan wawancara, pengukuran antropometri dan pemeriksaan kadar hemoglobin. Data faktor risiko dianalisis dengan
\end{abstract}


uji Regresi Poisson Multivariate. Hasil: Prevalensi anemia remaja putri di SMAN I Abiansemal sebesar 71,3\% (22,8\% anemia ringan, 47,2\% anemia sedang, dan 1,2\% anemia berat. Rata-rata usia remaja putri adalah $15,5 \pm 0,66$. Remaja putri yang hanya makan lengkap $\leq 2$ kali dalam sehari berisiko 1,59 kali menderita anemia $(95 \% C I=1,35-1,87) p$ value $=0,00$. Memiliki pantangan mengkonsumsi lauk hewani berisiko $1,22(95 \% C I=1,05-1,41)$ dan $p$ value $=0,009$. Remaja yang memiliki kebiasaan minum teh saat makan berisiko 1,22 kali menderita anemia $(95 \% C I=1,03$ 1,43). Lama menstruasi $\geq 6$ hari berhubungan dengan kejadian anemia dengan $P R=1,39$ $(95 \% C I: 1,18-1,62)$ dan nilai $p$ value $=0,00$. Analisis multivariat menunjukkan bahwa remaja yang memiliki keempat faktor risiko tersebut memiliki risiko menderita anemia sebesar 3 kali lebih tinggi $(\mathrm{aPR}=3,08 ; 95 \% C I=2,23-4,25)$. Simpulan: Prevalensi anemia remaja putri di SMAN I Abiansemal tergolong tinggi. Disarankan untuk melakukan skrining anemia secara berkala dan pemberian tablet besi secara rutin pada remaja putri. Diharapkan adanya kerja sama antara pelayanan kesehatan dengan sekolah dalam rangka peningkatan atau pengembangan program pencegahan dan penanggulangan anemia pada remaja putri melalui optimalisasi Program Kesehatan Peduli Remaja (PKPR)

Kata kunci : Anemia, Remaja putri, the, vegetarian

\section{PENDAHULUAN}

Anemia adalah suatu keadaan penurunan jumlah total kadar hemoglobin, hematokrit, dan jumlah sel darah merah lainnya hingga di bawah nilai normal yang ditetapkan. Anemia masih menjadi masalah kesehatan di negara berkembang maupun negara maju yang berdampak terhadap kesehatan sumber daya manusia, sosial dan ekonomi. WHO (2008) menggolongkan anemia menjadi masalah kesehatan masyarakat dalam 4 kriteria yaitu bukan masalah kesehatan (prevalensi $<5 \%$ ); masalah kesehatan ringan (prevalensi sebesar 5-19,9\%); masalah kesehatan tingkat sedang (prevalensi 20-39\%); dan merupakan masalah kesehatan tingkat berat (prevalensi $\geq 40 \%$ )

Prevalensi anemia pada wanita tidak hamil (15-49 tahun) di seluruh dunia sebesar 73,5\%, sebesar 85,4\% di kawasan Asia Tenggara dan pada anak usia sekolah (usia 5-14 tahun) sebesar 13,6\% (WHO, 2008). Prevalensi anemia pada wanita tidak hamil usia reproduksi di Indonesia sebesar 33,1\%. Data anemia berdasarkan Riskesdas tahun 2013, tercatat sebesar 26,4\% terjadi pada usia 5-14 tahun dan sebesar 18,4\% pada usia 15-24 tahun (Kemenkes RI, 2013) 
Remaja putri merupakan kelompok rawan menderita anemia karena dalam masa pertumbuhan dan setiap bulan mengalami menstruasi yang menyebabkan hilangnya zat besi. Anemia pada remaja putri vegetarian di Kabupaten Badung menunjukkan bahwa sebanyak 30\% remaja putri usia 12-21 tahun memiliki kadar hemoglobin $<12 \mathrm{gr} / \mathrm{dl}$ (Widarini, 2008). Studi ini bertujuan untuk mengetahui prevalensi dan faktor risiko anemia pada remaja putri di SMAN I Abiansemal, yang merupakan salah satu SMAN yang ada di wilayah Kabupaten Badung.

\section{METODE}

Penelitian ini menggunakan desain cross sectional analitik dengan melibatkan 254 orang siswa putri di SMAN I Abiansemal sebagai sampel yang memenuhi kriteria inklusi (telah mengalami menstruasi, bersedia dilakukan pengecekan kadar $\mathrm{Hb}$, bersedia dan kooperatif untuk diwawancara) dan kriteria eksklusi (sedang dalam keadaan sakit dalam jangka waktu proses pengumpulan data). Pengumpulan data dilaksanakan pada bulan November 2015. Alat yang digunakan untuk pengukuran antropometri adalah bathroom scale (berat badan) dan microtoise (tinggi badan). Kadar HB diukur menggunakan $\mathrm{Hb}$ meter digital merek Easy Touch (Rapid Diagnostic Test $\mathrm{Hb}$ dengan sensitivitas sebesar 98\%). Data faktor risiko anemia dikumpulkan melalui wawancara menggunakan kuisioner terstruktur. Data dianalisis menggunakan uji poisson regression with a robust variance estimator untuk melihat hubungan variabel bebas dengan variabel tergantung (Barros \& Hirakata, 2003; Coutinho, Scazufca, \& Menezes, 2008; Deddens \& Petersen, 2008; Zou, 2004).

\section{HASIL}

Hasil pemeriksaan kadar $\mathrm{Hb}$ menunjukkan bahwa sebanyak 71,3\% remaja putri di SMAN I Abiansemal mengalami anemia. Dari 254 orang remaja putri, sebanyak $22,8 \%$ mengalami anemia ringan, $47,2 \%$ anemia sedang, dan $1,2 \%$ mengalami anemia berat disajikan pada tabel 1 .

Analisis bivariat dilakukan untuk mengetahui hubungan beberapa faktor dengan kejadian anemia pada remaja putri di SMAN I Abiansemal. Hasil analisis bivariat dijabarkan pada tabel 2. Berdasarkan hasil analisis bivariat, remaja yang memiliki kebiasaan makan $\leq 2$ kali dalam sehari berisiko menderita anemia sebesar 1,6 
kali (PR 1,59; 95\% CI: 1,35-1,87). Adanya pantangan mengkonsumsi lauk hewani meningkatkan risiko anemia sebesar 22\% (PR=1,22; 95\%CI 1,05-1,41). Kebiasaan minum teh saat makan meningkatkan risiko anemia sebesar $22 \%$ (PR sebesar 1,22; 95\% CI: 1,03-1,43). Remaja putri yang mengalami menstruasi $>6$ hari memiliki risiko menderita anemia 1,39 kali lebih tinggi dibandingkan remaja yang mengalami menstruasi $\leq 6$ hari setiap siklus. Pada analisis multivariat dipilih model yang paling fit yang menggambarkan hubungan beberapa variabel bebas dengan variabel terikat kejadian anemia pada remaja putri berdasarkan nilai Bayesian information criterion (BIC). Nilai BIC paling kecil menunjukkan model yang paling baik juga mempertimbangkan nilai adjusted prevalence ratio $(a P R)$ dan $p$-value. Hasil analisis dijabarkan pada tabel 3.

Tabel 1 Kategori Anemia Remaja Putri di SMAN I Abiansemal Tahun 2015

\begin{tabular}{llll}
\hline Kategori & Kadar Hb (gr/dL) & Jumlah & $\mathbf{\%}$ \\
\hline Tidak anemia & $\geq 12,0$ & 73 & 28,7 \\
Anemia ringan & $11,0-11,9$ & 58 & 22,8 \\
Anemia sedang & $8,0-10,9$ & 120 & 47,2 \\
Anemia berat & $<8,0$ & 3 & 1,2 \\
Jumlah & & $\mathbf{2 5 4}$ & $\mathbf{1 0 0 , 0 0}$ \\
\hline
\end{tabular}

Tabel 3 Analisis multivariat faktor risiko anemia defisiensi besi pada remaja putri di SMAN I Abiansemal

\begin{tabular}{|c|c|c|c|c|c|}
\hline \multirow{2}{*}{ No } & \multirow{2}{*}{ Variabel } & \multicolumn{2}{|l|}{ Model 1} & \multicolumn{2}{|l|}{ Model 2* } \\
\hline & & aPR $(95 \% C I)$ & $p$-value & aPR $(95 \% C I)$ & p-value \\
\hline 1 & Pengetahuan & $1,01(0,99-1,01)$ & 0,681 & & \\
\hline 2 & $\begin{array}{l}\text { Frekwensi makan } \\
\text { lengkap dalam sehari }\end{array}$ & $1,55(1,32-1,81)$ & 0,000 & $1,55(1,32-1,81)$ & 0,000 \\
\hline 3 & $\begin{array}{l}\text { Pantangan lauk } \\
\text { hewani }\end{array}$ & $1,23(1,07-1,41)$ & 0,002 & $1,23(1,08-1,41)$ & 0,002 \\
\hline 4 & $\begin{array}{l}\text { Minum teh saat } \\
\text { makan }\end{array}$ & $1,18(1,01-1,36)$ & 0,032 & $1,17(1,01-1,36)$ & 0,031 \\
\hline 5 & Lama menstruasi & $1,35(1,17-1,56)$ & 0,000 & $1,35(1,17-1,56)$ & 0,000 \\
\hline \multicolumn{2}{|c|}{$\mathrm{BIC}$} & & 501,078 & & 495,579 \\
\hline \multicolumn{2}{|c|}{ Pseudo R2 } & & 0,0347 & & 0,0346 \\
\hline
\end{tabular}


Tabel 2 Hasil Analisis Bivariat faktor risiko anemia pada remaja putri di SMAN I Abiansemal

\begin{tabular}{|c|c|c|c|c|c|}
\hline \multirow{2}{*}{ No } & \multirow{2}{*}{ Variabel } & \multicolumn{2}{|l|}{ Anemia } & \multirow{2}{*}{$\begin{array}{l}\mathrm{PR} \\
(95 \% C I)\end{array}$} & \multirow{2}{*}{$\begin{array}{l}p \\
\text { value }\end{array}$} \\
\hline & & Ya & Tidak & & \\
\hline \multirow[t]{4}{*}{1} & Umur & & & & \\
\hline & Observasi & $181(71,26)$ & $73(28,74)$ & $0,94(0,83-1,06)$ & 0,320 \\
\hline & Mean \pm SD & $15,47 \pm 0,65$ & $15,57 \pm 0,74$ & & \\
\hline & Min-Max & $14-18$ & $14-18$ & & \\
\hline \multirow[t]{4}{*}{2} & Indek Masa Tubuh (IMT) & & & & \\
\hline & Observasi & $181(71,26$ & $73(28,74)$ & $0,99(0,97-1,02)$ & 0,644 \\
\hline & Mean \pm SD & $21,55 \pm 3,62$ & $21,77 \pm 3,27$ & & \\
\hline & Min-Max & $13,84-32-85$ & $16,63-33,3$ & & \\
\hline \multirow[t]{4}{*}{3} & Tingkat Pengetahuan & & & & \\
\hline & Observasi & $181(71,26$ & $73(28,74)$ & $1,01(0,99-1,01)$ & $0,153^{*}$ \\
\hline & Mean \pm SD & $74,58(11,17)$ & $73,32(10,73)$ & & \\
\hline & Min-Max & $30-100$ & $50-90$ & & \\
\hline \multirow[t]{3}{*}{4} & & & & & \\
\hline & $\begin{array}{l}\text { pend. dasar } \\
\text { pend. menengah }\end{array}$ & $\begin{array}{l}28(75,68) \\
124(70,06)\end{array}$ & $\begin{array}{l}9(24,32) \\
53(29,94)\end{array}$ & $\begin{array}{l}1,04(0,80-1,36) \\
0.96(0,77-1,19)\end{array}$ & $\begin{array}{l}0,751 \\
0,754\end{array}$ \\
\hline & pend. tinggi & $29(72,50)$ & $11(27,50)$ & pembanding & \\
\hline \multirow[t]{3}{*}{5} & Pendapatan Keluarga & & & & \\
\hline & $<\mathrm{UMR}$ & $55(62,50)$ & $33(37,50)$ & $0,82(0,68-0,98)$ & 0,038 \\
\hline & $\geq \mathrm{UMR}$ & $126(75,90)$ & $40(24,10)$ & & \\
\hline \multirow[t]{3}{*}{6} & Frekwensi makan lengkap & & & & \\
\hline & $\leq 2$ kali sehari & $105(88,98)$ & $13(11,02)$ & $1,59(1,35-1,87)$ & $0,000^{*}$ \\
\hline & $>2$ kali sehari & $76(55,88)$ & $60(44,12)$ & & \\
\hline \multirow[t]{3}{*}{7} & Pantangan Lauk Hewani & & & & \\
\hline & Ya & $62(81,58)$ & $14(18,42)$ & $1,22(1,05-1,41)$ & $0,009 *$ \\
\hline & tidak & $119(66,85)$ & $59(33,15)$ & & \\
\hline \multirow[t]{3}{*}{8} & Makan sayur setiap hari & & & & \\
\hline & tidak & $65(73,86)$ & $23(26,14)$ & $1,06(0,90-1,24)$ & 0,496 \\
\hline & $\mathrm{Ya}$ & $116(69,88)$ & $50(30,12)$ & & \\
\hline \multirow[t]{3}{*}{9} & Minum teh saat makan & & & & \\
\hline & $\mathrm{Ya}$ & $107(77,54)$ & $31(22,46)$ & $1,22(1,03-1,43)$ & $0,020^{*}$ \\
\hline & tidak & $74(63,79)$ & $42(36,21)$ & & \\
\hline \multirow[t]{3}{*}{10} & Mengikuti program diet & & & & \\
\hline & Ya & $30(69,77)$ & $13(30,23)$ & $0.97(0,78-1,20)$ & 0,817 \\
\hline & tidak & $151(71,56)$ & $60(28,44)$ & & \\
\hline
\end{tabular}


Tabel 2 Hasil Analisis Bivariat faktor risiko anemia pada remaja putri di SMAN I Abiansemal (lanjutan)

\begin{tabular}{|c|c|c|c|c|c|}
\hline No & Variabel & Anemia & Tidak & $\begin{array}{l}\text { PR } \\
(95 \% C I)\end{array}$ & $\begin{array}{l}p \\
\text { value }\end{array}$ \\
\hline 11 & $\begin{array}{l}\text { Siklus Menstruasi } \\
\text { tdk teratur }\end{array}$ & $66(70,97)$ & $27(29,03)$ & $0,99(0,84-1,16)$ & 0,938 \\
\hline \multirow{4}{*}{12} & teratur & $115(71,43)$ & $46(28,57)$ & & \\
\hline & Lama menstruasi & & & & \\
\hline & $\geq 6$ hari & $99(83,90)$ & $19(16,10)$ & $1,39(1,18-1,62)$ & $0,000^{*}$ \\
\hline & $<6$ hari & $82(60,29)$ & $54(39,71)$ & & \\
\hline
\end{tabular}

Pada awal analisis variabel pengetahuan dimasukkan dalam model, kemudian diperoleh nilai $p$ pada variabel pengetahuan $>0,05$ sehingga harus dikeluarkan dari model. Setelah dilakukan analisis tanpa variabel pengetahuan tidak temukan adanya perubahan nilai $a P R$ pada variabel lainnya hingga $10 \%$. Hal ini berarti variabel pengetahuan bukan merupakan variabel pengganggu atau bukan variabel antara. Model 2 dikatakan paling fit karena memiliki nilai BIC dan nilai Pseudo R2 yang paling kecil.

Pada model 2 dijelaskan bahwa frekuensi makan $\leq 2$ kali dalam sehari serta mengalami menstruasi $>6$ hari memiliki efek yang paling besar terhadap kejadian anemia pada remaja putri dilihat berdasarkan nilai kemaknaan ( $p$ value). Model 2 menjelaskan bahwa frekuensi makan $\leq 2$ kali meningkatkan risiko anemia pada remaja sebesar 55\%. Adanya pantangan mengkonsumsi lauk hewani meningkatkan risiko anemia sebesar $23 \%$. Kebiasaan minum teh saat makan meningkatkan risiko kejadian anemia sebesar 17\%. Hasil analisis juga menunjukkan bahwa remaja yang mengalami menstruasi $>6$ hari berisiko mengalami anemia sebesar 35\%.

Persamaan regresi yang terbentuk dengan koefisien masing-masing variabel bebas adalah:

$y=\left(e^{\beta 0}\right) x\left(e^{\beta_{1} x_{1}}\right) x\left(e^{\beta_{2} x_{2}}\right) x\left(e^{\beta_{k} x_{k}}\right)$
$y=(e)^{-0,88}(e)^{0,44^{*}}(e)^{0,21 x_{2}}(e)^{0,16 x_{3}}(e)^{0,31 x_{4}}$ $y=-0.88+0.44 *$ frekmakan $+0.21 *$ tdkmakanla ukhewani $+0.16 *$ teh $+0.31 *$ lamamenstr uasi 
Remaja yang makan lengkap $\leq 2$ kali, memiliki pantangan untuk makan lauk/protein hewani, memiliki kebiasaan minum teh saat makan, dan durasi menstruasi $\geq 6$ hari memiliki risiko untuk menderita anemia 3 kali lebih tinggi $(\mathrm{aPR}=3,08 ; 95 \% \mathrm{CI}$ 2,23-4,25).

\section{Pembahasan}

Hasil penelitian anemia pada remaja putri di SMAN I Abiansemal Badung Bali menunjukkan angka yang cukup tinggi yaitu sebesar 71,3\%. Berdasarkan kategori WHO, ditemukan bahwa sebanyak 28,7\% memiliki kadar Hb normal, sebanyak 22,8\% anemia ringan, sebanyak 47,2\% anemia sedang, dan sebanyak 1,2\% anemia berat. Prevalensi anemia tersebut dapat dinyatakan sebagai masalah kesehatan masyarakat karena lebih tinggi dari batas klasifikasi yaitu $\leq 40 \%$ (WHO, 2011). Prevalensi anemia remaja putri di India dilaporkan bahwa pada kelompok ekonomi rendah terjadi sebesar 96,5\%, pada kelompok ekonomi menengah ke atas terjadi 65,18\% (Gawarika, Gawarika, \& Mishra, 2006). Penelitian di India pada remaja usia 10 - 18 tahun ditemukan bahwa jumlah anemia ringan pada remaja sebanyak 50,5\%, anemia sedang sebanyak 29\% dan anemia berat sebanyak 20,5\% (Thomas, Chandra, Sharma, Jain, \& Pemde, 2015). Angka kejadian anemia pada remaja putri di Kavar, Iran Selatan ditemukan sebesar 5,8\% (Ramzi et al., 2011).

Berdasarkan analisis multivariat, faktor yang berhubungan dengan kejadian anemia pada remaja putri adalah frekuensi makan lengkap dalam sehari, memiliki pantangan mengkonsumsi lauk hewani, memiliki kebiasaan minum teh saat makan, dan lama menstruasi. Rata-rata wanita mengkonsumsi $6,5 \mu \mathrm{g}$ zat besi per hari. Jumlah ini masih jauh dari Angka Kebutuhan Gizi (AKG) zat besi yang dianjurkan yaitu $26 \mu \mathrm{g}$ per hari. Berdasarkan hasil penelitian remaja putri yang hanya makan lengkap $\leq 2 \mathrm{kali}$ dalam sehari memiliki risiko menderita anemia sebesar 1,6 kali lebih tinggi dibandingkan dengan remaja yang memiliki kebiasaan makan makanan lengkap $>2$ kali dalam sehari. Usia remaja merupakan usia peralihan dari anak-anak menjadi dewasa. Remaja membutuhkan nutrisi yang lebih banyak untuk proses pertumbuhan dan perkembangan. Penyebab anemia di Indonesia diketahui pada wanita usia 15-19 tahun 
sebanyak 23,1\% disebabkan oleh karena rendahnya konsumsi daging, ikan, dan hati. Sebanyak 28, 5\% disebabkan karena rendahnya konsumsi sayur dan buah, dan sebanyak 9,9\% oleh karena malnutrisi (WHO, 2011)

Terdapat 2 bentuk zat besi di dalam bahan makanan, yaitu non heme dan heme (Bothwell,1995; Charlton \& Bothwell 1983 dalam Charles, 2012) . Zat besi dalam bentuk heme terdapat di dalam daging, ikan, dan daging ayam. Zat besi non heme lebih mudah dicerna oleh tubuh dan tidak dipengaruhi oleh inhibitor zat besi. Sementara itu zat besi non heme yang membentuk $90 \%$ zat besi dalam tubuh, berasal dari makanan non daging (biji-bijian, sayur, buah dan telur) lebih sulit diserap oleh tubuh (Harvey et $a l ., 2000)$. Jenis zat besi yang dikonsumsi lebih penting dibandingkan kuantitas, akan tetapi jika jenis dan jumlah yang kurang maka akan berdampak pada rendahnya kadar zat besi dalam darah. Jika seseorang memiliki pantangan atau tidak mengkonsumsi bahan pangan hewani atau daging, berarti terjadi kekurangan sumber zat besi heme yang justru sangat mudah diserap oleh tubuh. Berdasarkan hasil analisis remaja putri yang memiliki pantangan mengkonsumsi lauk hewani memiliki risiko 1,22 kali lebih tinggi untuk menderita anemia. Terdapat hubungan yang signifikan antara vegetarian dengan kejadian anemia berat pada remaja (Verma, et.al ,1998 dalam Thomas et al., 2015). Kaur et al (2006) menyatakan bahwa remaja putri yang menjalankan vegetarian memiliki risiko lebih tinggi menderita anemia (OR:5,83; 95\%CI:3,73-9,13)

Konsumsi zat besi heme diketahui dapat meningkatkan penyerapan zat besi non heme yang ditemukan dalam tanaman. Asam fitat yang merupakan bentuk simpanan fosfor pada tanaman ditemukan terutama pada biji-bijian dan kacang, dapat mengganggu penyerapan zat besi non heme. Dengan mengurangi konsumsi makanan tinggi asam fitat seperti kopi, teh, kacang-kacangan dan sereal pada saat makan akan meningkatkan zat besi. Teknik pengolahan makanan seperti fermentasi, tunas dan perendaman juga dapat mengurangi efek inhibitor dari asam fitat (Charles, 2012). Hasil penelitian ini menunjukkan bahwa remaja yang memiliki kebiasaan minum teh pada saat makan berisiko menderita anemia 1,22 kali lebih tinggi atau berisiko sebesar 22\% menderita anemia yang dilihat pada nilai PR:1,22; 95\% CI: 1,03-1,43 
Remaja putri yang mengalami menstruasi $\geq 6$ hari setiap satu siklus menstruasi berisiko menderita anemia defisiensi besi sebesar 1,39 kali lebih tinggi dibandingkan remaja yang mengalami masa menstruasi $<6$ hari selama 1 siklus. Data World Health Organization (2011) menunjukkan bahwa kejadian anemia pada remaja putri usia 1519 tahun di Indonesia, sebanyak 1,9\% disebabkan oleh karena menstruasi.

Rata-rata seorang wanita mengeluarkan darah sebanyak $27 \mathrm{ml}$ setiap siklus menstruasi 28 hari. sebanyak 10\% wanita diduga kehilangan darah lebih dari $80 \mathrm{ml}$ per bulan. volume darah yang keluar saat menstruasi berperan pada kejadian anemia karena wanita tidak mempunyai persediaan zat besi yang cukup (Warrilow et al., 2004 dalam Widarini, 2010). Remaja dengan perdarahan yang berlebihan saat menstruasi memiliki risiko lebih besar untuk menderita anemia $(\mathrm{OR}=5,65 ; \mathrm{CI}=1,26-25,28)$

Hubungan variabel bebas secara keseluruhan dengan kejadian anemia remaja putri di SMAN I Abiansemal dianalisis secara multivariat dalam sebuah pemodelan. Model yang paling fit menggambarkan hubungan variabel bebas dengan variabel tergantung dipilih berdasarkan nilai BIC yang paling kecil. Hasil analisis menggambarkan bahwa jika secara bersama-sama variabel frekuensi makan lengkap dalam sehari $\leq 2$ kali, memiliki pantangan mengkonsumsi lauk hewani, memiliki kebiasaan minum the saat makan serta mengalami menstruasi $\geq 6$ hari, maka besarnya risiko seorang remaja menderita anemia adalah sebesar 3 kali lebih tinggi yang dilihat pada nilai aPR sebesar 3,08 (95\%CI: 2,23-4,25) dengan nilai kemaknaan $<0,05$.

\section{SIMPULAN DAN SARAN}

Prevalensi anemia defisiensi besi pada remaja putri di SMAN I Abiansemal sebesar $71,3 \%$. Faktor risiko yang berhubungan dengan kejadian anemia adalah frekuensi makan lengkap; adanya pantangan makan lauk hewani; memiliki kebiasaan minum teh saat makan; lama menstruasi $\geq 6$ hari. Hal yang dapat disarankan adalah diharapkan adanya skrining anemia dan pemberian tablet besi pada remaja putri secara berkala di sekolah serta adanya kerja sama antara puskesmas/pelayanan kesehatan dan sekolah dalam rangka pengembangan program pencegahan dan penanggulangan anemia pada remaja putri. 


\section{UCAPAN TERIMAKASIH}

Kami mengucapkan terimakasih kepada siswa putri SMAN I Abiansemal yang bersedia dengan kooperatif selama proses pengumpulan data. Terimakasih kepada enumerator yang telah membantu proses pengumpulan data. Terimakasih kepada Akper Kesdam IX/Udayana yang mendanai penelitian ini secara penuh.

\section{DAFTAR PUSTAKA}

Barros, A. J. D., \& Hirakata, V. N. (2003). Alternatives for logistic regression in crosssectional studies: An empirical comparison of models that directly estimate the prevalence ratio. BMC Medical Research Methodology, 3, 1-13. https://doi.org/10.1186/1471-2288-3-21

Charles, C. . (2012). Iron Deficiency Anemia: A Public Health Problem of Global Proportions. Public Health - Methodology, Environmental and Systems Issues. https://doi.org/10.5772/37655

Coutinho, L. M. S., Scazufca, M., \& Menezes, P. R. (2008). Methods for estimating prevalence ratios in cross-sectional studies. Revista de Saúde Pública, 42(6), 992998. Retrieved from http://www.ncbi.nlm.nih.gov/pubmed/19009156

Deddens, J. A., \& Petersen, M. R. (2008). Approaches for estimating prevalence ratios. Occupational and Environmental Medicine, 65(7), 501-506. https://doi.org/10.1136/oem.2007.034777

Gawarika, R., Gawarika, S., \& Mishra, A. . (2006). Prevalence of Anaemia in Adolescent Girls Belonging to Different Economic Group. Indian Journal of Community Medicine, 31(4), 287-288.

Kaur, S., Deshmukh, P. ., \& Garg, B. . (2006). Epidemiological Correlates of Nutritional Anemia in Adolescent Girls of Rural Wardha. Indian Journal of Community Medicine, 31(4), 255-258.

Kemenkes RI. (2013). Riset Kesehatan Dasar 2013. In Badan Penelitian dan Pengembangan Kesehatan Kemenkes RI (Vol. 6). https://doi.org/1 Desember 2013

Ramzi, M., Haghpanah, S., Malekmakan, L., Cohan, N., Baseri, A., Alamdari, A., \& Zare, N. (2011). Anemia and iron deficiency in adolescent school girls in kavar urban area, southern iran. Iranian Red Crescent Medical Journal, 13(2), 128-133. Retrieved from http://www.pubmedcentral.nih.gov/articlerender.fcgi?artid=3371916\&tool=pmc entrez\&rendertype $=$ abstract 
Thomas, D., Chandra, J., Sharma, S., Jain, A., \& Pemde, H. K. (2015). Determinants of nutritional anemia in adolescents. Indian Pediatrics, 52(10), 867-869. https://doi.org/10.1007/s13312-015-0734-7

WHO. (2008). Worldwide Prevalence of Anaemia 1993-2005:WHO Global Database on Anaemia (B. de Benoist, E. McLean, I. Egli, \& M. Cogswell, Eds.). WHO.

Widarini, N. P. (2008). Asupan zat gizi dan kejadian anemia pada remaja putri vegetarian di Kabupaten badung provinsi Bali.

World Health Organization. (2011). Prevention of iron deficiency anaemia in adolescents. In WHO-SEARO. https://doi.org/10.1109/VTC.1982.1623054

Zou, G. (2004). A Modified Poisson Regression Approach to Prospective Studies with Binary Data. American Journal of Epidemiology, 159(7), 702-706. https://doi.org/10.1093/aje/kwh090 